\title{
Anatomy, Age and Evolution of the Baltoro granite batholith, Pakistani Karakoram
}

\author{
Michael Searle ${ }^{1 *}$, Andrew Thow ${ }^{1}$, Randall Parrish ${ }^{2}$, Steve Noble ${ }^{2}$ and David Waters ${ }^{1}$ \\ 1 Department of Earth Sciences, University of Oxford, Oxford OX1 3PR, UK \\ 2 Department of Geology, University of Leicester, Leicester LE1 7RH, UK; and NERC Isotope Geoscience Laboratory, British Geological Survey, \\ Keyworth, Nottingham NG12 5GG, UK. \\ * For correspondence, email: mikes@earth.ox.ac.uk
}

Geological mapping around the Baltoro granite batholith in North Pakistan has resulted in a more detailed picture of the 3-D anatomy of the batholith. U-Th-Pb geochronology on all the main intrusive phases has resulted in more detailed timing constraints on batholith evolution. The Karakoram terrane in North Pakistan, shows abundant evidence for Middle Jurassic and Cretaceous (170-90 Ma) Andean-type subduction-related granite intrusion (eg: K2, Muztagh Tower gneisses, Hunza granodiorites, Hushe gneisses). Following collision and accretion of first the Kohistan Arc, and later the Indian plate to the southern margin of Asia, crustal thickening along the Karakoram resulted in polyphase deformation, and multiple 'phases' of metamorphism and melting (Searle and Tirrul 1991; Fraser et al.2001). The major phase of kyanite- and sillimanite-grade metamorphism in the Baltoro region was Oligocene - Lower Miocene (28-22 Ma; U$\mathrm{Pb}$ monazite ages). A widespread network of leucogranitic dykes that cross-cut folds and regional fabrics has been dated at 24.7 $\pm 0.6 \mathrm{Ma}$ (U-Pb zircon) indicating that major thickening and folding was over by that time. Renewed deformation and heating in the middle-lower crust to sillimanite $+\mathrm{K}$-feldspar grade with migmatisation and generation of gem-bearing leucogranite dykes occurred in the deep crustal Dassu gneiss dome in the southern Karakoram between $5.5-3.5 \pm 0.2 \mathrm{Ma}$ (U-Pb zircon, monazite). The Baltoro granite batholith, previously dated between 25-20 Ma (Parrish and Tirrul 1989, Schärer et al. 1990, Searle et al. 1992) also includes Early Miocene granites. New U-Pb monazite ages from crustal melt biotite + muscovite + garnet leucogranites from the Trango Towers, Cathedral peak and Paiyu peak span $19.8-17.5 \pm 0.5 \mathrm{Ma}$. The youngest leucogranites from the huge sheeted sill complex that feeds the Masherbrum garnet-bearing 2 mica leucogranite are the youngest dated phases in the Baltoro batholith at $17.6 \pm 1.1 \mathrm{Ma}$. The Masherbrum and $\mathrm{K} 7$ granites extend east to the Siachen glacier region where they are cut abruptly by the Karakoram strike-slip fault, indicating that the fault must have initiated after $17 \mathrm{Ma}$, in common with earlier $\mathrm{U}-\mathrm{Pb}$ dating constraints from the Tangtse region (Phillips et al. 2004).

\section{References}

Fraser, JE, MP Searle, RR Parrish and SR Noble. 2001. Chronology of deformation, metamorphism and magmatism in the southern Karakoram Mountains. Geological Society of America Bulletin 113: 1443-1455

Parrish, RR and R Tirul. 1989. U-Pb age of the Baltoro granite, northwest Himalaya, and implications for monazite U-Pb systematics. Geology 17: 1076-9

Phillips, RJ, RR Parrish and MP Searle. 2004. Age constraints on ductile deformation and long-term slip rates along the Karakoram fault zone, Ladakh. Earth and Planetary Science Letters 226: 305-319

Schärer U, P Copeland, TM Harrison and MP Searle. 1990. Age, cooling history and origin of post-collisional leucogranites in the Karakoram batholith: a multi-system isotope study N. Pakistan. J. Geology 98: 233-251

Searle MP and R Tirrul. 1991. Structural and thermal evolution of the Karakoram crust. Journal of Geological Society, London 148: 65-82

Searle, MP, MB Crawford and AJ Rex. 1992. Field relations, geochemistry, origin and emplacement of the Baltoro granite, Central Karakoram. Transactions Royal Society, Edinburgh 83: 519-538 